\title{
THE INFLUENCE OF SHORT TERM, INTENSIVE HIPPOTHERAPY ON GAIT IN CHILDREN WITH CEREBRAL PALSY
}

\author{
Markku Honkavaara*'Pauli Rintala** \\ * Physical Education, Helsinki, Finland. \\ ** Department of Sport Sciences, University of Jyväskylä, Finland
}

\begin{abstract}
The purpose of this study was to investigate the effects of short term hippotherapy on functional gait changes in children with cerebral palsy (CP). Participants were two boys (ages 12 and 13) with spastic diplegia and a girl (14 yrs) with athetoid CP. Single-subject (ABA) design was used to determine quantitative changes in functional gait parameters (velocity, stride length, and cadence) following three weeks of hippotherapy. The two boys demonstrated improvement in stride length and gait velocity without sustained improvement in cadence. There was increase in stride length and cadence, but most noticeable improvements in velocity for the girl. The results indicated that it is possible that short-term hippotherapy may improve functional gait in children with cerebral palsy.
\end{abstract}

\section{KEYWORDS:Hippotherapy, Cerebral palsy, Gait analysis, Single subject study}

\section{INTRODUCTION}

Due to the location and extent of the central nervous system lesion, the neuromotor characteristics of individuals with cerebral palsy $(\mathrm{CP})$ vary greatly. A non-progressive disorder of voluntary movement and posture, a specific diagnosis is dependent upon the level of motor dysfunction and associated involvement. Common secondary consequences of these lesions may include spasticity and contractures across joints that lead to observable gait abnormalities (Gage, 1991; Sutherland \& Davids, 1993). According to Gage (1991) typical features of gait in CP are: 1) loss of selective muscle control; 2) difficulties with balance; 3 ) abnormal muscle tone; 4) agonist and antagonist imbalance; and 5) dependence on primitive reflexes for ambulation (athethoid).

Spasticity in CP refers to lowered threshold in stretch reflex, which causes abnormal velocity dependent increases in muscle tone (Damiano et al., 2002), hence faster movements tend to increase spasticity in antagonist muscles in CP. When compared to typical gait this leads to more restricted stride length.

The energy required for ambulation in $\mathrm{CP}$ may be three to fourfold compare to 'normal' walking (Johnston, Moore, Quinn, \& Smith, 2004; Sutherland \& Davids, 1993). This inefficiency is primarily due to the cocontraction of muscles, particularly the hamstrings and quadriceps working against each other at mid-swing phase of gait cycle (Berger, Qintern, \& Diez, 1982; Gage, Perry, Hicks, Koop, \& Werntz. 1987; Gage, 1993; Winter 1990). Because of this immaturely developed neurological regulation of gait (resembles early stages of child's gait), there is only a limited chance to increase walking velocity (Berger, Altenmueller \& Diez, 1984).

When compared with a normative population children with $\mathrm{CP}$ walk slower. Skrotzky (1983) revealed reduced stride length in children with $\mathrm{CP}$ to be the main factor of slower gait velocity. The length of stride is related to the severity of neuromuscular dysfunction. Skrotzky (1983) also found asymmetry in gait components, 
abnormality in movement patterns and high intra-subject variability in children with $\mathrm{CP}$. Although abnormal reflexes, spasticity, contractures, etc. are in their part responsible for difficulties in ambulation, the standing equilibrium reactions are the most important determinants for functional walking of a child with CP (Bleck 1987; Gage \& Novacheck, 2001).

Therapeutic priorities for children with $\mathrm{CP}$ include the prevention of long term neuromotor complications and maintenance/improvement of activities of daily living (ADL) (Rommel, 1993; Strauss, 1991). Walking is often considered the primary goal when planning rehabilitation for children with CP (Bleck, 1987). Trend has been towards more functional approaches in treatment of CP (Siebes et al., 2002). Biofeedback, swimming, hippotherapy, electrical stimulation, and strength training programs are some novel approaches (Siebes, Wijnroks, \& Vermeer, 2002). It is possible to increase muscle strength in CP (Scholtes, et al., 2010). The effects of physical exercise have been examined in several studies: results suggest that increasing lower extremity strength may be beneficial and improve motor function (Verschuren, Ketelaar, Takken, Helders, \& Gorter, 2008). There is still some controversy over the effectiveness physical training because there is a lack of evidence that is based on well designed experimental trials (Siebes et al., 2002; Palmer, 1997, Vershuren et al.,2008). One review even concluded that strength training does not lead to therapeutically meaningful outcomes in $\mathrm{CP}$ (Scianni, Butler, Ada, \& Teixeira-Salmela, 2009).

Therapeutic horseback riding has demonstrated positive therapeutic benefits in $\mathrm{CP}$ including: improved standing posture (Bertoti, 1988) and sitting posture (Wingate 1982); decreased spasticity (Zahrádka 1993); improvement in fine motor function of hands (MacKinnon et al., 1995); reduced energy expenditure in walking (McGibbon, et al., 1998); improvements in muscle symmetry (Benda, McGibbon, \& Grant, 2003); increase in Gross Motor Function Measure's scores
(Casady \& Nichols-Larsen, 2004; Cherng et al., 2004; McGibbon, et al., 1998; Sterba, Rogers, France, \& Vokes, 2002; Winchester, Kendal, Peters, Sears, \& Winkley, 2002); reduced muscle asymmetry during walking and functional motor skills (McGibbon, Benda, Duncan, \& Silkwood-Sherer, 2009).

In hippotherapy the focus is not on interaction or learning the equestrian skills as is the case in adapted riding (Casady \& Nichols-Larsen, 2004). In hippotherapy the horse's walking (gait) is the basic component used to produce neurophysiologic therapeutic effects on the rider. The client has to adapt him- or herself to the altering physical forces. Horse's swinging movements are producing three-dimensional dynamic and rhythmic impulses that are transmitted to the rider. These impulses are exposing the rider to forward and backward movements, shifts sideways, and rotations. The pattern of these movements resembles the human gait (Blum, 1993; Riede, 1983; Strauss, 1991; Taufkirchen, 1993; Ölsböck, 1992). To maintain the balance the rider has to be active. The movements of the horse stimulate the vestibular system and proprioception of the rider, and also activate the tactile and motor sensory systems. The sensory input through riding and integration of sensory stimulation is improving equilibrium reactions for walking and enhancing the spatial and body awareness of the client. Transmitted dynamic movements, and stretch in muscles and tendons, are normalizing the muscle tone and movement patterns (Rommel, 1993; Strauss, 1991). Hippotherapy is purported to improve postural control, balance and overall motor performance, and the special elements of horses gait are employed to facilitate correct walking patterns in children with CP (Bertoti, 1988; Haehl, Giuliani, \& Lewis, 1999; Meregillano, 2004; Taufkirchen, 1993).

Although the improvement of walking is one of the main therapeutic goals of hippotherapy, there is a paucity of empirical data about its effects on gait in children with CP. Therefore, the purpose of this study was 
to investigate the effects of short term hippotherapy on functional gait changes in children with $\mathrm{CP}$. The primary interest was to document the functional quantitative changes and the secondary interest was to describe the possible qualitative changes in gait following hippotherapy.

\section{Method}

Participants

Participants were two boys (ages 12 and 13) with spastic diplegia and a girl (14 yrs) with athetoid CP. All participants were ambulatory, two requiring assistive devices, and able to walk at least $40 \mathrm{~m}$ while demonstrating a normal reciprocating gait as determined by the participants' physical therapist. A history of lower extremity surgery was not a criterion for exclusion, and all wore bilateral dynamic ankle foot orthoses (DAFO's).

Participants had not participated in hippotherapy for a minimum of six months prior to the onset of the study. All children had average (or above) intelligence, were currently under the care of a physical therapist, and not taking medications. Informed consent was given by the parents and assent provided by the children. Descriptive data for the children can be found in Table 1.

Table 1.

Participants' data (DAFO's = dynamic ankle foot orthoses)

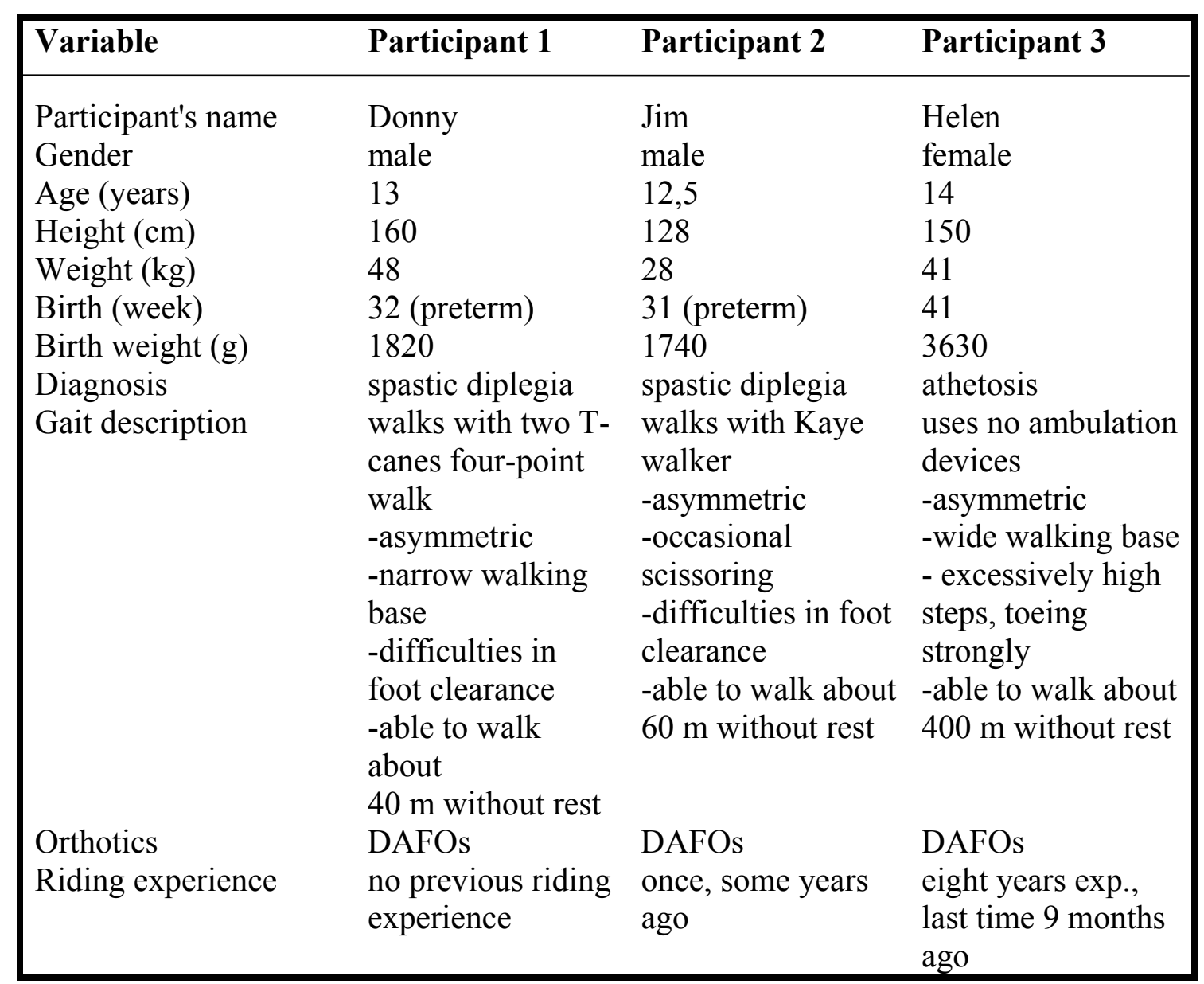


This study employed a single-subject ABA withdrawal design with repeated measures within-subjects (Kazdin, 1982) to investigate changes in gait velocity, stride length and cadence following three weeks of intensive hippotherapy.
Each participant completed three separate phases including: baseline (A), intervention (B), and withdrawal (A). Prior to the beginning of baseline measurements, participants completed three separate familiarization sessions (Figure 1).

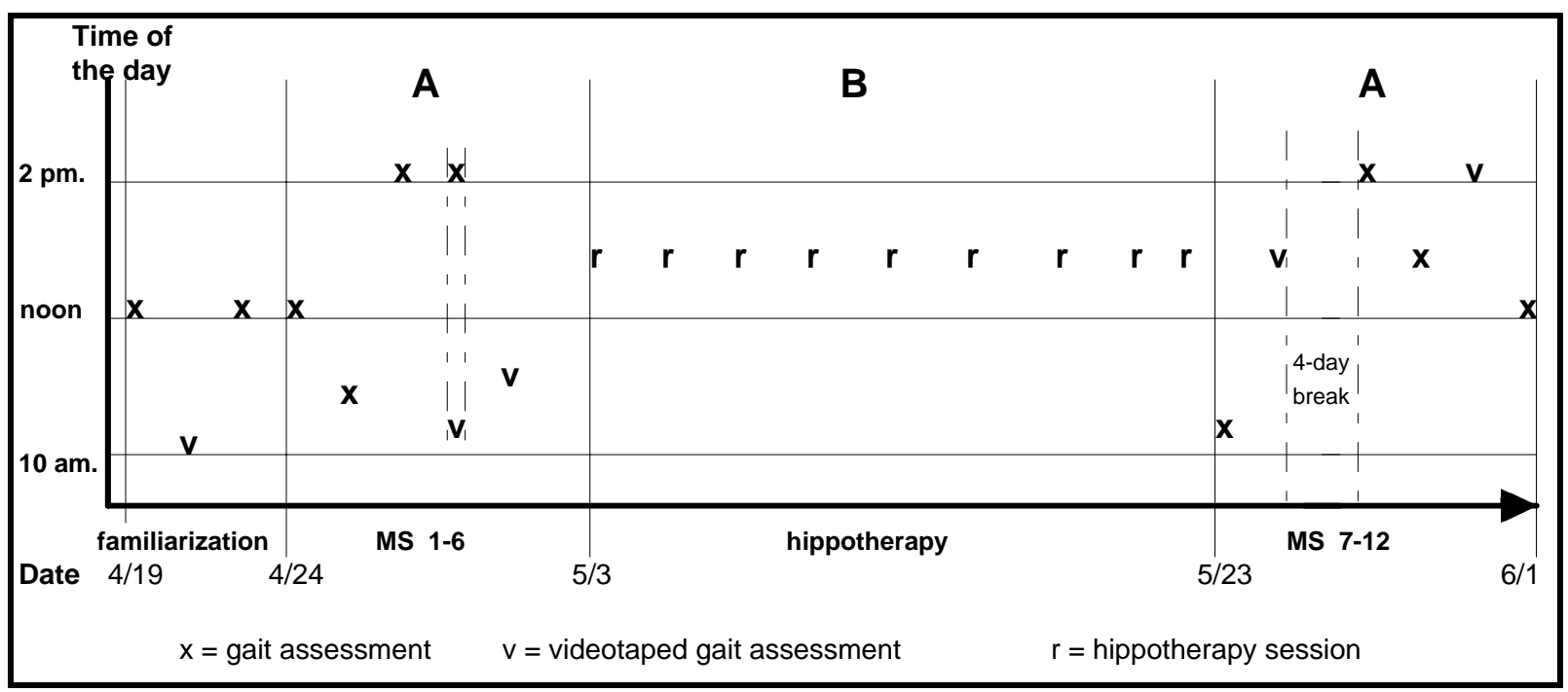

Figure 1.

Progression of the empirical phase. Gait assessments (MS 1-12) and hippotherapy program are presented based on dates and time of the day.

The objectivity of the study required a valid quantitative assessment tool measuring the functional change in walking. Practicality and simplicity were two important criteria for choosing the method. Valid results are more likely to be achieved in familiar settings (such as a school gymnasium) than in very complex ones, especially when children are participants. Quoting Whittle (1991): "An intrusive measurement system and a cluttered laboratory environment might not worry a fit adult, who was acting as an experimental subject, but could cause a significant change in the gait of a child with CP." (p. 175)

\section{Instruments}

Quantitative gait parameters. The children were instructed to initiate walking when ready and proceed at a self-selected (i.e., normal, free, comfortable) pace down a $15.5 \mathrm{~m}$ walkway (Figure 2). The self selected walking speed is widely used and considered to give sufficient and most relevant information in gait analysis (Brown, Rodda, Walsh, \& Wright, 1991; Himann, Cunningham, Rechnizer, \& Paterson, 1988; Leonard, Hirschfeld, \& Forssberg, 1991; Mattsson, Ohlsson, \& Broström L-Å, 1990; Mattsson, Broström, Borg, \& Karlsson, 1990; Richards, Malouin, \& Dumas, 1991; Robinson, \& Smidt, 1981; Wheelwright, Minns, Law, \& Elton, 1993a, 1993b. Results from Olsson et al. (1986) showed that free and maximal walking velocity were the best indicators of walking function. Trials with maximum speed or different speeds are suggested by Andriacchi et al. (1977), but for subjects with neurological impairment this may cause technical difficulties (Brown et al., 1991). Hirokawa and Matsumara (1987) found that free walking velocity had the 
lowest coefficient of variation when compared with slow and fast speeds.

Using a stopwatch, taped line and video camera (for estimating visually posture and symmetry of gait), gait parameters were measured within a $10 \mathrm{~m}$ section as previously described by Rose, Ounpuu and DeLuca (1991) and Sutherland, Ohlsen, Cooper and Woo (1982). The steps were counted, the time was taken, and the exact distance was measured from the footprints left in a thin layer of magnesium powder spread in both ends (approximately 1 meter after the start and stop lines) of the $10 \mathrm{~m}$ section of the walkway. After each walk the bottoms of the shoes were cleaned with a wet rag, and when necessary, the walkway was cleaned. The same part of the same foot started and ended the walk for the purpose of establishing stride length. When the child was ready for walking, he or she was helped to the starting position about $3 \mathrm{~m}$ behind the line where the step was to leave the first footprint. There was enough space after the $10 \mathrm{~m}$ line to stop walking without difficulty.

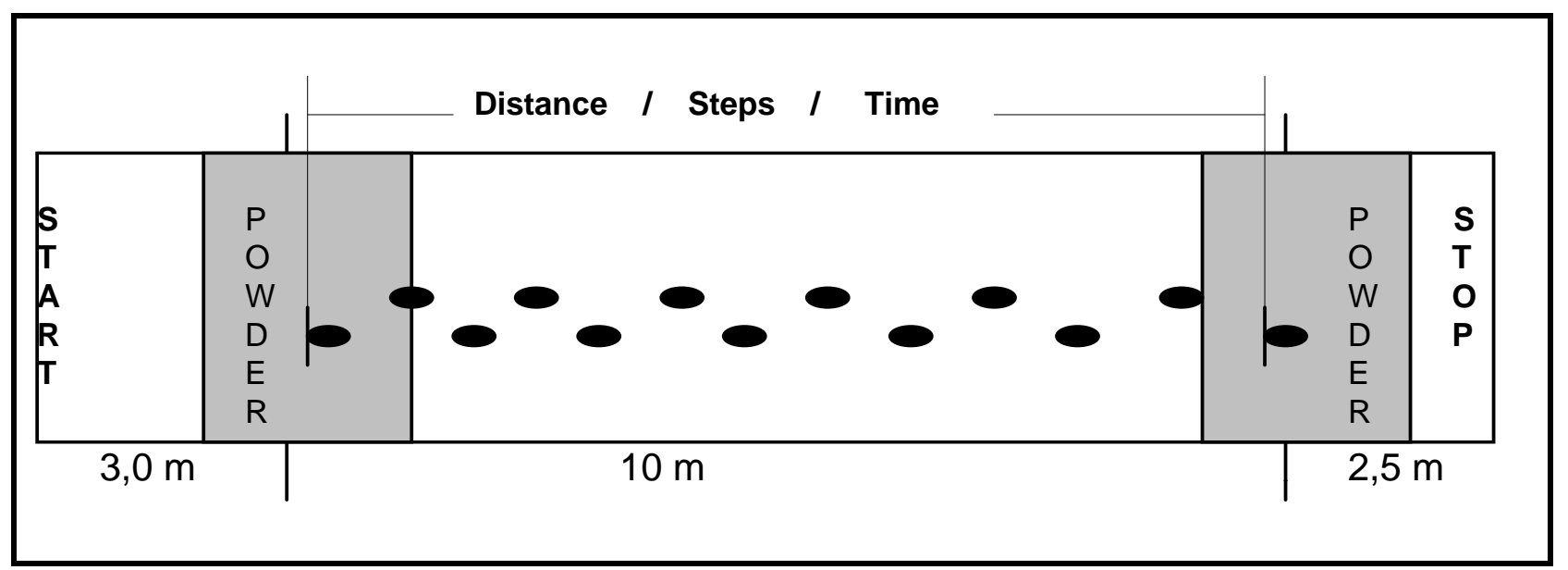

Figure 2.

Measuring walkway

\section{Procedure}

The participants' physical therapist was responsible for preparing the children for the walking trials. This included checking that children wore: the same shoes and DAFO's during each measurement session (MS); their orthoses correctly; non-restrictive garments. Prior to MS, each child had a short warm-up session. Throughout each MS, the physical therapist also checked the quality of gait (in order not to include gait trials that were fatally atypical, e.g., based on slipping in the beginning, or 'sitting' on the walker). The MS was concluded upon the completion of three successful appropriate trials.

The baseline phase (Phase A) of the study consisted of six baseline gait measurement sessions (MS 1-6) arranged over five consecutive days the week before the introduction of the intervention (Phase B).
Due to large variability frequently seen in gait measures among individuals with $\mathrm{CP}$, there were two MS's on day four to estimate internal consistency within participants.

\section{Intervention}

The intensive hippotherapy program (B) was planned and implemented by a qualified riding therapist, who is also a physical therapist, experienced in working with children with neurological impairments. An experienced equestrian was responsible for controlling and leading the horse with long reins throughout the session. The two horses used throughout the intervention were trained specifically for therapeutic purposes. Participants rode without a saddle to maximize the therapeutic effects for the rider (Strauss, 1991). The participants held a safety belt that attached around the horse's trunk. As 
the participants became more comfortable riding; balance activities (releasing grip and holding arms upward, outward, etc.) were gradually added to the sessions.

The program consisted of nine separate hippotherapy sessions (r) for each participant and was conducted over three consecutive weeks. The goal of the hippotherapy program was strictly the improvement of gait. The program was designed according to hippotherapeutic principles as presented in the introduction. The initial riding session lasted 25 minutes, and gradually increased by $1-2$ min per session as tolerated to a maximum of 40 minutes of actual riding time. Pilot work suggested that fatigue due to intensity of therapy negatively influenced gait performance up to two days posthippotherapy, therefore, no measurements were done during the intervention phase.

During the intervention phase children's daily routines proceeded as normally as possible. It was agreed upon with the families and professionals that there would be no changes in activities and therapy that would possibly cause abrupt variation in the daily activities of the children.

The week immediately following the intervention phase, the withdrawal phase (A) began. The first two gait assessments (MS 78) of the withdrawal phase were carried out on the next two days immediately after the last hippotherapy session. This was considered important in order to verify the fatigue effect of intervention on gait that was seen in the pilot testing. It was hypothesized that the benefits of the intervention would be seen only after a recovery period, thus the last four gait assessments (MS 9-12) would describe the "true effect" of the hippotherapy intervention.

\section{Qualitative gait observation}

Several gait assessments (MS 4, 6, 8 and 11) were also videotaped. The children wore swimsuits and relevant anatomical reference points on major joints were marked with black ink spots. Two video cameras were used; one anterior and a second moving parallel with the participant. The videotape examination was used for a secondary purpose of this study to provide additional information about the observable qualitative changes in gait. The quality of gait was evaluated from the videotapes by three physiotherapists. This is important in evaluating the therapeutic value of the results (Kazdin, 1982).

\section{Data Analysis}

Within single-subject research design, Kazdin (1982) suggests two approaches to evaluate data in order to draw conclusions about behavior chance: experimental criterion and therapeutic criterion. The experimental criterion is based on a comparison of behavior under different conditions (baseline phase $\{A\}$ and intervention phase $\{B\})$. It refers to the way in which data are evaluated to determine if an intervention has had a reliable or veridical effect on behavior. Therapeutic criterion means that there is practically meaningful improvement in participant's function.

Experimental criterion in single-subject designs can be evaluated using visual and/or statistical analysis of data. The traditional and most used approach in analyzing single-subject data is visual inspection of the graphic displays. According to Kazdin (1982) visual analysis "refers to reaching a judgment about the reliability or consistency of intervention effects by visually examining graphed data." (p. 232). Visual inspection of plotted data is subjective, but it depicts only powerful intervention results that are, when visible, likely to represent meaningful behavior change (Alberto \& Troutman, 1999, p. 209). The experimental control is achieved in single-subject studies by assessing repeatedly one subject's behavior in two conditions: without exposing the participant to the intervention and after intervention has introduced (Kazdin, 1982) and using baseline logic (Johnston \& Pennypacker, 1993).

The dependent variables analyzed in this study were stride length, cadence and gait 
velocity. The visual change in each parameter within participant is presented in the figures 3-5. Data points within each MS 1-12 include mean and highest and lowest score. Each data point is relative to the mean of all parameter scores which was marked as $100 \%$-line. Calculating mean $/ 100 \%$ included three trials in every MS 1-12, hence consisted of 36 individual trials. For example, when Donny's total mean of all stride length scores was $56,8 \mathrm{~cm}(=100 \%)$, then MS1 mean score $51,0 \mathrm{~cm}$ equals $89,8 \%$, and MS 11 mean score $67,1 \mathrm{~cm}$ equals $118 \%$ in the figure 3 .

The effects of the hippotherapy program on the gait parameters were calculated as percentage changes comparing the baseline means before (MS 1-6) and after intervention (MS 9-12). The first two gait assessments (MS 7-8) of the withdrawal phase verified the hypothesis that fatigue negatively influenced gait. As a result these two data sessions were eliminated from calculating the effect. It was hypothesized that the benefits of the intervention would be demonstrated after a one-week recovery period (MS 9-12). Since variability within each measurement session was large, the change after the intervention had to be clear to demonstrate a positive effect.

The therapeutic criterion in this study was estimated based on percentage change. Since there is no previous scientific basis for determining the exact magnitude of meaningful positive change it had to be decided based on rational thinking.

The positive interpretation of the therapeutic effect was based on the following criteria: (a) no individual mean score from MS 1-6 above the mean of MS 9-12, (b) no mean score of MS 9-12 under the $100 \%$ line, and (c) no overlapping individual mean scores between MS 1-6 and MS 9-12. This was decided to show clearly enough the change, since the presented criteria somewhat controls the volatility because overlapping of scores confuse the non-statistical interpretation.
The therapeutic effect was further studied with visual inspection of videotaped qualitative data. From the videotape analysis, three experienced physical therapists each independently determined positive changes in functional gait following intervention. The effect was verified and reported only if all three experts had depicted the same change in function.

\section{RESULTS}

Figure 3 demonstrates the intervention outcomes for Donny.

Stride length. The restriction in Donny's stride length was clear when compared with normative values (Donny's score 0.54 vs. normative values of $1.06-1.64 \mathrm{~m}$ ) (Table 2). Visual inspection determined a trend toward increasing of stride length of MS 9-12. There was a $17 \%$ improvement (approximately $9 \mathrm{~cm}$ improvement per stride) when the mean of MS 9-12 was compared with the mean of MS 1-6. These results suggest that hippotherapy increased stride length.

Cadence. Although there was a slight improvement in cadence, the variability (overlap) between MS 1-6 and MS 9-12 does not allow a definitive conclusion about the benefits of riding on cadence for Donny.

Velocity. Compared to his same-aged peers one would describe Donny's walking as very slow $(0.35$ vs. $0.95-1.67 \mathrm{~m} / \mathrm{s})$. The mean improvement after the riding therapy program was $20 \% \quad$ (Table 2). This discernible improvement in velocity was obvious despite moderate variation between MS 9-12.

Qualitative analysis. Donny's standing posture was improved as seen in a decreased forward lean of the trunk. It appeared that he had less flexion in the lower extremities and decreased scapular-thoracic protraction allowing more upright posture and apparently less dependence on his canes that were now held closer to the body. The physical therapists also reported that Donny had differentiated movements in the pelvis and the trunk only after the intervention. There was decreased internal rotation of the right hip and decreased 'toe in' positioning in stance. 
Donny's gait could be described more symmetrical as seen with improvement in his right leg step length. This may partially explain the $17 \%$ increase in stride length.

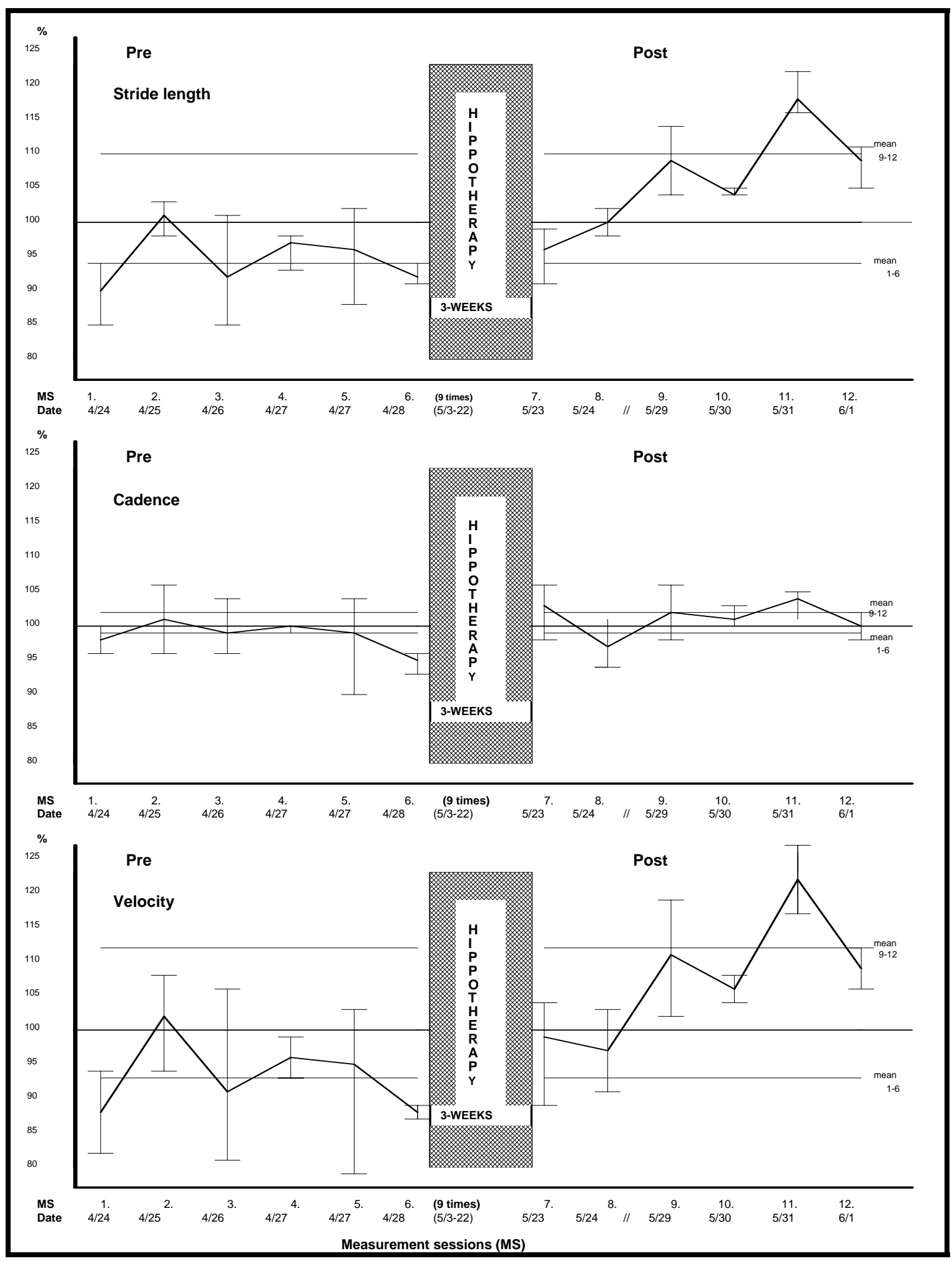

Figure 3. Donny: Gait parameters before (phase A), hippotherapy program (B), and after (A) 
Table 2.

Mean values of gait parameters before (MS 1-6) and after (MS 9-12) intervention, percentage change, and normal range

\begin{tabular}{|c|c|c|c|}
\hline Variable & Donny & Jim & Helen \\
\hline \multicolumn{4}{|l|}{ Stride length $(\mathrm{cm})$} \\
\hline 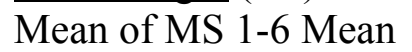 & 53.66 & 71.21 & 115.64 \\
\hline of MS 9-12 & 62.60 & 77.03 & 121.51 \\
\hline Difference & $16.7 \%$ & $8.2 \%$ & $5.1 \%$ \\
\hline Normal range* & $106-164$ & $96-154$ & $99-155$ \\
\hline \multicolumn{4}{|l|}{ Cadence (steps/min) } \\
\hline \multicolumn{4}{|l|}{ Mean of MS 1-6 } \\
\hline Mean of MS 9-12 & 78.02 & 86.49 & 103.11 \\
\hline Difference & 80.59 & 89.07 & 108.80 \\
\hline \multirow[t]{2}{*}{ Normal range* } & $3.3 \%$ & $3.0 \%$ & $5.5 \%$ \\
\hline & $100-149$ & $105-156$ & $103-150$ \\
\hline \multicolumn{4}{|l|}{ Velocity $(\mathrm{cm} / \mathrm{s})$} \\
\hline \multicolumn{4}{|l|}{ Mean of MS 1-6 } \\
\hline Mean of MS 9-12 & 34.94 & 51.30 & 99.40 \\
\hline Difference & 42.00 & 57.22 & 110.14 \\
\hline \multirow[t]{2}{*}{ Normal range* } & $20.2 \%$ & $11.5 \%$ & $10.8 \%$ \\
\hline & $95-167$ & $88-160$ & $90-162$ \\
\hline \multicolumn{4}{|l|}{$\begin{array}{l}\text { explained by } \\
\text { improvement in: } \\
\text { Stride length }\end{array}$} \\
\hline Cadence & $83 \%$ & $73 \%$ & $48 \%$ \\
\hline & $17 \%$ & $27 \%$ & $52 \%$ \\
\hline
\end{tabular}

*Age and gender specific normal ranges

(Whittle 1991)

Figure 4 demonstrates the intervention outcomes for Jim.

Stride length. Compared with normative values for 12 year olds $(0.71$ vs. $0.96-1.54 \mathrm{~m})$, Jim's stride length was significantly shorter (Table 2). There was an $8 \%$ increase in Jim's stride length (MS 9-12) that stabilized during the last three measurement sessions. These results suggest that the hippotherapy positively influenced stride length.

Cadence. Like Donny, Jim also had slight improvement in cadence (3\%).
Although there was low variability between measurement sessions, there was one individual MS 1-6 above mean MS 912 , and an overlap of means between MS 1-6 and MS 9-12. These results do not allow a definitive conclusion about the benefits of riding on cadence for Jim.

Velocity. Jim's walking would be characterized as slow compared with his same-aged peers ( 0.51 vs. $0.88-1.60 \mathrm{~m} / \mathrm{s})$. The mean improvement after the hippotherapy was $12 \%$ (Table 2). This definite increase in velocity was evident 
despite large variation within MS 10-11 and a slight overlap of MS 3 with MS 9 and 12 .
Qualitative analysis. Jim carried his trunk more upright. He also had reduced crossing of the feet and relied less on his walker for support, while walking looked more rhythmic and relaxed.

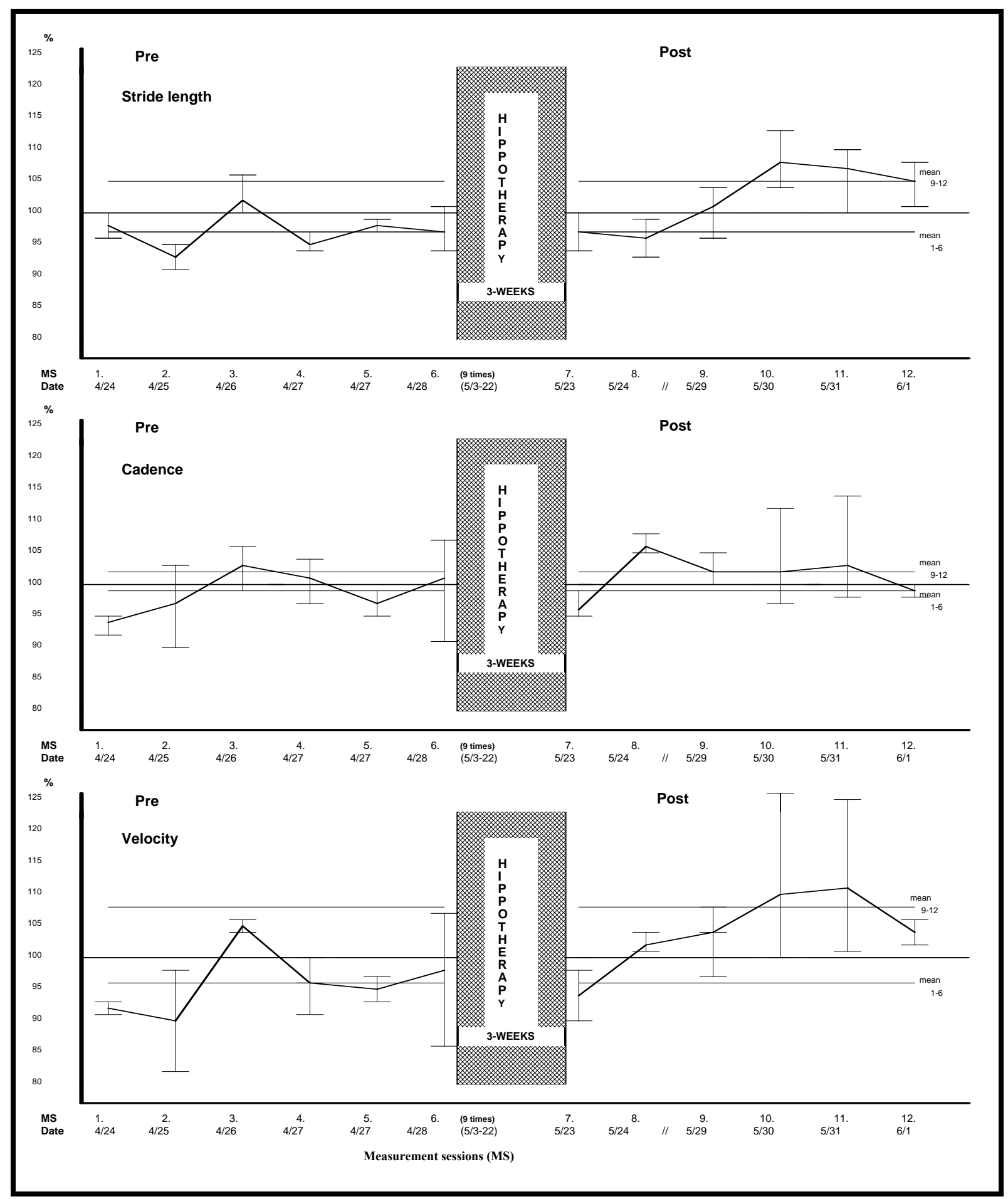

Figure 4.

Jim: Gait parameters before (phase A), hippotherapy program (B), and after (A) 
Figure 5 demonstrates the intervention outcomes for Helen.

Stride length. Helen's stride length was within the normative values for her age (1.15 vs. $0.99-1.55 \mathrm{~m})$ (Table 2), and increased 5\% following intervention. Visible improvements in stride length were seen followed by a downward, but variable trend. According to our criteria it seemed that hippotherapy had to some extent improved the stride length of Helen.

Cadence. Compared to Donny and Jim, Helen's improvement in cadence was larger (6\%), although her baseline values were within normative range.
While MS 9 showed definitive improvement, the downward trend of MS 10-12 and the overlap of MS 6 with MS 12 suggested no therapeutic effect.

Velocity. Helen's walking speed $(0.99$ vs. $0.90-1.62 \mathrm{~m} / \mathrm{s})$ (Table 2$)$ was at the lower end of the normative values for her age and gender. Her greatest velocity was obtained at MS 9 followed by the downward trend in MS 10-12. Nevertheless, there was an overall positive change of $11 \%$ in velocity.

Qualitative analysis. Videotape evaluation did not reveal any consistent findings for Helen.

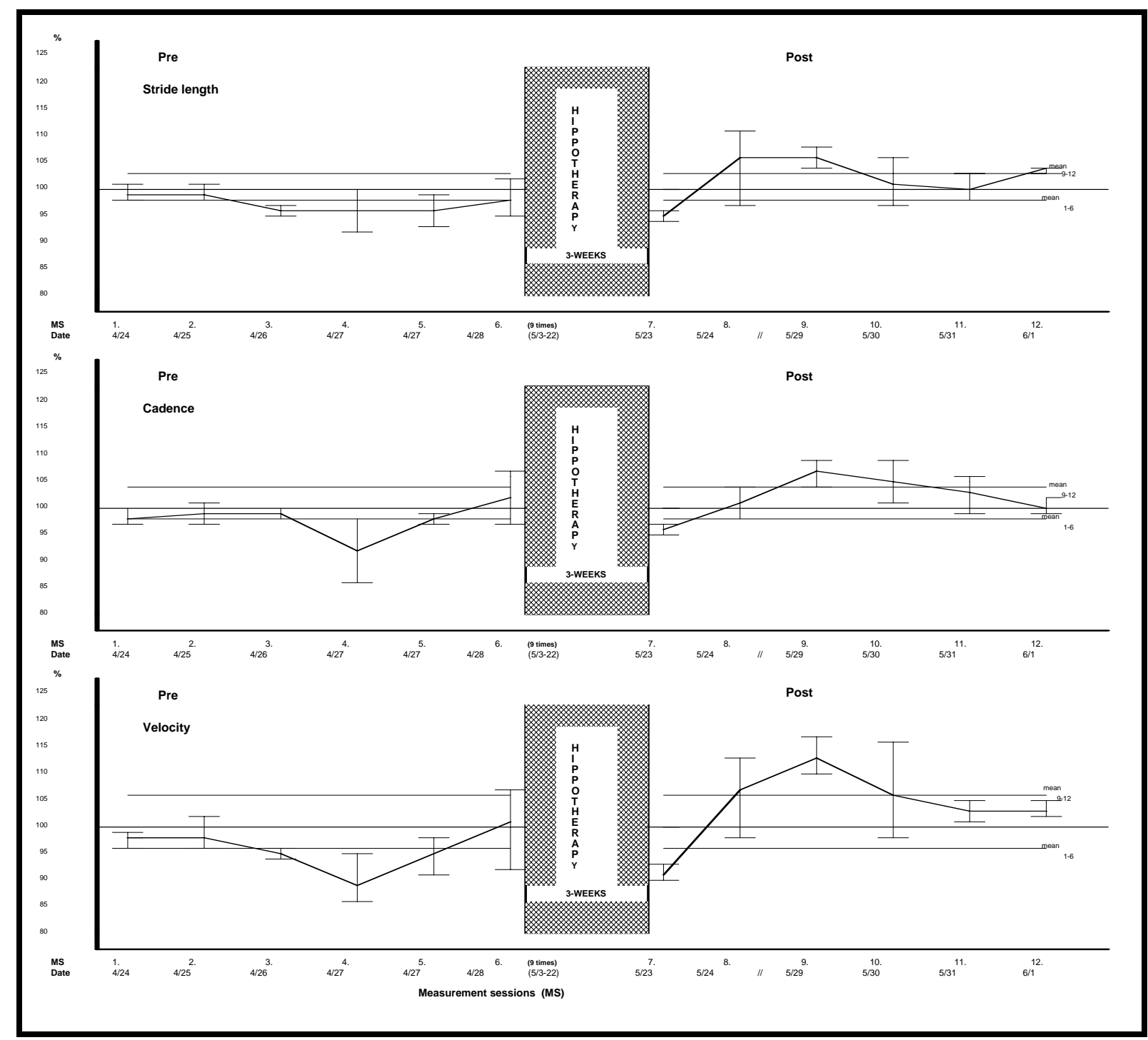

Figure 5.Helen: Gait parameters before (phase A), hippotherapy program (B), and after (A) 


\section{DISCUSSION}

Previous studies have shown hippotherapy has beneficial functional outcomes on children with $\mathrm{CP}$ following twice weekly 8 and 10 week interventions (Bertoti, 1988; McGibbon et al., 1998). The primary purpose of this study was to investigate the effects of a short term (3 week), intensive (thrice weekly) hippotherapy program on functional gait in three children with CP.

The results showed greatest percentage change in stride length of two boys with spastic diplegia. Positive improvements in the quality of gait were also recorded following independent videotape analysis. This positive change in stride length is in accordance with the findings of Abel and Damiano (1996) that children with spastic CP have slow gait velocities due to restrictions in stride length. Gait velocity is dependent on two components: stride length and cadence. Stride length explained $83 \%$ of the improvement of velocity for Donny and $73 \%$ for Jim (Table 2).

Helen's stride length and cadence were equally responsible for the positive change in velocity. This seems logical since there was no clear restriction in stride length or cadence compared with baseline normative values. Helen's steps could be considered only slightly short and, therefore, no radical change in velocity could be expected. One possible cause for minimal improvement may be due to the fact that Helen's baseline measures were within normal parameters for 14 year-old girls. Based on the videotapes the therapists reported that the nature of Helen's athetoid gait approximated a typical gait pattern, and that small improvements and/or changes were visually difficult to differentiate without digital analysis.

The expected degree of therapeutic input was greater for the two boys with spastic diplegia without previous hippotherapy treatment than for Helen. Unlike the boys, Helen had extensive previous riding experience prior to the onset of the investigation which may partially explain her minimal improvement. Helen did however demonstrate more confidence in her ability to ambulate independently following this intervention after having discontinued hippotherapy for 9 months prior to the onset of this study. We can only speculate that Helen's renewed interest and participation in an intensive hippotherapy program allowed her to ambulate confidently yet with minimal improvement in gait measurements.

Stride length improvements in our participants with spastic diplegia is consistent with findings from McGibbon et al. (1998), yet the cause of these improvements is unknown. Future research should investigate differences between the mechanism of improvement in gait between spastic diplegia and the athetoid gait following hippotherapy. Improvement in cadence was found to be small in our study that differed from the anticipated results reported previously. McGibbon et al. (1998) found cadence to decrease in five children with $\mathrm{CP}$ following hippotherapy and likewise, Sutherland et al. (1980) reports that gait pattern improvements seen in non-disabled individuals typically reveal a decreased cadence with an increased stride length. Our participants all increased their cadence, velocity and stride length after hippotherapy

The great variability in performance within and between sessions was a striking and common feature in the results of all participants. Intra-subject fluctuations in motor performance are typical in cerebral palsy (Skrotzky, 1983; Whittle, 1991; Fetters $\&$ Kluzik, 1996). Another characteristic of the three participants was that there seemed to be a fatigue effect on gait. This was seen in the two MS 7-8 just after the intervention. Also there appeared to be recovery from the strenuous exercise and improvement in gait parameters when compared to the baseline before the intervention. These features are visible in the similar slopes of stride length and velocity of Donny, Jim, and Helen. Visual inspection of the single-subject graphs reveals that Helen responded differently in MS 7-8 than did either of the two boys. It appeared that Helen recovered more quickly than either of the boys perhaps due to the fact that she had 
previous riding experience and especially that the boys' spastic muscles were relatively more strained by hippotherapy treatment.

The gait assessment procedure used in this study appears to be a useful tool for determining physical therapy treatment outcomes significantly related to functional gait status (Holden, Gill, Magliozzi, \& PiehlBaker, 1984; Rose et al., 1991; Sutherland et al., 1980). The single-subject design does not allow for generalizations beyond this group of participants with spastic and athetoid CP.

Test-retest results using this method have been reported to be a highly reliable way to measure temporal and distance parameters in human gait. Pearson correlation coefficients have been reported to vary between $.92-.98$ for test-retest reliability (Holden et al., 1984). Our observations support these findings, since test-retest reliability was found to range from .86 to .99 during MS 4-5.

\section{Conclusion and Recommendations}

This study presented the effect of a short-term hippotherapy program on gait in three children with CP. Even though the results showed functional improvement especially in the gait of the two boys with spastic diplegia, and gave some subjective explanations, replications are needed to confirm the results. The importance of this study was also in giving the basis for planning a more comprehensive method, possibly combined with assessments in gait laboratory. Another outcome of this study was to present a practical tool for the therapists to assess the outcome of therapy. There is sufficient evidence of the validity of the gait assessment procedures used in this research. This study showed the usefulness and relative practicality of the method to measure treatment outcome on gait. The long-term effects of hippotherapy are a topic to be studied in the future. A comprehensive investigation that includes an intensive hippotherapy intervention followed by a long maintenance period with occasional evaluations will provide valuable information on the long term effectiveness of hippotherapy on children with $\mathrm{CP}$.

\section{REFERENCES}

Abel, M. F., \& Damiano, D. L. (1996). Strategies for increasing walking speed in diplegic cerebral palsy. Journal of Pediatric Orthopaedics, 16:753-758.

Alberto, P. A., \& Troutman, A. C. (1999). Applied Behavior Analysis for Teachers. New Jersey: Prentice-Hall.

Andriacchi, T. P., Ogle, J. A., \& Galanti, J.O. (1977). Walking speed as a basis for normal and abnormal gait measurements. Journal of Biomechanics, 10:261-268.

Benda, W., McGibbon, N. H., \& Grant, K. L. (2003). Improvements in muscle symmetry in children with cerebral palsy after equineassisted therapy (hippotherapy). Journal of Alternative and Complementary Medicine, 9:817-825.

Berger, W., Altenmueller, E., \& Diez, V. (1984). Normal and impaired development of childrens gait. Human Neurobiology, 3:163-170.

Berger, W., Qintern, J., \& Diez, V. (1982). Pathophysiology of gait in children with cerebral palsy. Electroencephalography and Clinical Neuropsychology, 53:538-548.

Bertoti, D. B. (1988). Effect of therapeutic horseback riding on posture in children with cerebral palsy. Physical Therapy, 68:15051512.

Bleck, E. E. (1987). Orthopaedic Management in Cerebral Palsy. Clinics in Developmental Medicine, London: Mac Keith Press, No.99/100.

Blum, M. (1993). Die Bewegung des Pferdes als Rehabilitationsmöglichkeit [The horse's movement as a rehabilitative possibility]. Therapeutisches Reiten, 20:17-21.

Brown, J. K., Rodda, J., Walsh, E.G., \& Wright, G.W. (1991). Neurophysiology of lower-limb function in hemiplegic children. Developmental Medicine and Child Neurology, 33:1037-1047.

Casady, R. L. \& Nichols-Larsen, D. S. (2004). The effect of hippotherapy on ten children with cerebral palsy. Pediatric Physical Therapy, 16:165-172.

Cherng, R-J., Liao, H-F., Leung, H. W. C., \& Hwang, A-W. (2004). The effectiveness of 
therapeutic horseback riding in children with spastic cerebral palsy. Adapted Physical Activity Quarterly, 21, 103-121.

Damiano, D. L., Quinlivan, M. E., Owen, B. F., Payne, P., Nelson, K. C., \& Abel, M. F. (2002). What does Ashworth scale really measure and are instrumented measures more valid and precise? Developmental Medicine and Child Neurology, 44, 112118.

Fetters, L., \& Kluzik, J. (1996). The effects of neurodevelopmental treatment versus practice on the reaching of children with spastic cerebral palsy. Physical Therapy, 76, 346-358.

Gage, J. R. (1991). Gait Analysis in Cerebral Palsy. Oxford: Mac Keith Press.

Gage, J. R. (1993). Gait analysis: an essential tool in the treatment of cerebral palsy. Clinical Orthopaedics and Related Research, 288:126-134.

Gage, J. R. \& Novacheck, T. F. (2001). An update on the treatment of gait problems in cerebral palsy. Journal of Pediatric Orthopaedics Part B, 10:265-274.

Gage, J. R., Perry, J., Hicks, R.R., Koop, S., Werntz, J.R. (1987) Rectus femoris transfer to improve knee function of children with cerebral palsy. Developmental Medicine and Child Neurology, 29:159-166.

Haehl, V., Giuliani, C., \& Lewis, C. (1999). Influence of hippotherapy on the kinematics and functional performance of two children with cerebral palsy. Pediatric Physical Therapy, 11:89-101.

Himann, J. R., Cunningham, D. A., Rechnizer, P. A., \& Paterson, D.H. (1988). Age-related changes in speed of walking. Medicine and Science in Sports and Exercice, 20:161-166.

Hirokawa, S., \& Matsumara, K. (1987). Gait analysis using a measuring walkway for temporal and distance factors. Medical \& Biological Engineering \& Computing, 25:577-582.

Holden, M. K., Gill, K. L., Magliozzi, M. R., \& Piehl-Baker, L. (1984). Clinical gait assessment in the neurologically impaired: reliability and meaningfulness. Physical Therapy, 64:35-40.

Johnston, T. E., Moore, S. E., Quinn, L. T., \& Smith (2004). Energy cost of walking in children with cerebral palsy: Relation to gross motor function classification system. Developmental Medicine and Child Neurology, 46:34-38.

Johnston, J. M., \& Pennypacker, H. S. (1993). Strategies and tactics of Behavioral research ( $\left.2^{\text {nd }} e d.\right)$. Hillsdale, NJ: Erlbaum.

Kazdin, A. E. (1982). Single-Case Research Designs: Methods for Clinical and Applied Settings. New York: Oxford University Press.

Leonard, C. T., Hirschfeld, H., \& Forssberg, H. (1991). The development of independent walking in children with cerebral palsy. Developmental Medicine and Child Neurology, 33:567-577.

MacKinnon, J. R., Noh, S., Laviere, J., MacPhail, A., Allan, D. E., \& Laliberte, D. (1995). A study of therapeutic effects of horseback riding for children with cerebral palsy. Physical \& Occupational Therapy in Pediatrics, 15:17-34.

Mattsson, E., Broström, L. A., Borg, J., \& Karlsson, J. (1990). Walking efficiency before and after long-term muscle stretch in patients with spastic paraparesis. Scandinavian Journal of Rehabilitation Medicine, 22:55-59.

Mattsson, E., Ohlsson, E., \& Broström, L. A. (1990). Assessment of walking before and after unicompartmental knee arthroplasty. Scandinavian Journal of Rehabilitation Medicine, 22:45-50.

McGibbon, N. H., Andrade, C-K., Widener, G., \& Cintas, H. L. (1998). Effect of an equine movement therapy program on gait, energy expenditure, and motor function in children with spastic cerebral palsy: a pilot study. Developmental Medicine and Child Neurology, 40:754-762.

McGibbon, N. H., Benda, W., Duncan, B. R., \& Silkwood-Sherer, D. (2009). Immediate and long-term effects of hippotherapy on symmetry of adductor muscle activity and functional ability in children with spastic 
cerebral palsy. Archives of Physical Medicine and Rehabilitation, 90:966-974

Meregillano, G. (2004). Hippotherapy. Physical Medicine and Rehabilitation Clinics of North America, 15:843-854.

Olsson, E., Goldie, J., \& Wykman, A. (1986). Total hip replacement. A comparison of Charnley (cemented) and HP Garches (noncemented) fixation. Scandinavian Journal of Rehabilitation Medicine, 18:102-108.

Palmer, F. (1997). Evaluation of developmental therapies in cerebral palsy. Mental Retardation and Developmental Disabilities, 3:145-152.

Poon, D. M. \& Hui-Chan, C. W. (2009). Hyperactive stretch reflex, co-contraction, and muscle weakness in children with cerebral palsy. Developmental Medicine and Child Neurology, 51:128-135.

Richards, C. L., Malouin, F., \& Dumas, F. (1991). Effects of single session of prolonged plantarflexor stretch on muscle activations during gait in spastic cerebral palsy. Scandinavian Journal of Rehabilitation Medicine, 23:103-111.

Riede, D. (1983). Beschleunigungs- und Schwingungsmessungen auf dem Pferdrücken und am Reiter [Acceleration and swing measurements on horseback and rider] . Krankengymnastik, 35:10-13.

Robinson, J. L., \& Smidt, G. L. (1981). Quantitative gait evaluation in the clinic. Physical Therapy, 61:351-353.

Rommel, T. (1993). Hippotherapie unter dem Aspekt der Neurorehabilitation [Hippotherapy from the perspective of neurological rehabilitation]

Therapeutisches Reiten, 20:3-6.

Rose, S. A., Ounpuu, S., \& DeLuca, P. A. (1991). Strategies for the assessment of pediatric gait in the clinical setting. Physical Therapy, 71:961-980.

Scholtes, V. A., Becher, J. G., Comuth, A., Dekkers, H., Van Dijk, L., \& Dallmeijer, A. J. (2010). Effectiveness of functional progressive resistance exercise strength training on muscle strength and mobility in children with cerebral palsy: a randomized controlled trial. Developmental Medicine and Child Neurology, 52:107-113.
Scianni, A, Butler, J. M., Ada, L., \& TeixeiraSalmela, L. F. (2009). Muscle strengthening is not effective in children and adolescents with cerebral palsy: a systematic review. Australian Journal of Physiotherapy, 55: 81-87.

Siebes, R. C., Wijnroks, L., \& Vermeer, A. (2002). Qualitative analysis of therapeutic motor intervention programs for children with cerebral palsy: An update. Developmental Medicine \& Child Neurology, 44:593-603.

Skrotzky, K. (1983). Gait analysis in cerebral palsied and nonhandicapped children. Archives of Physical Medicine and Rehabilitation, 64:291-295.

Strauss, I. (1991). Neurophysiologische Krankengymnastik auf dem Pferd [Neurophysiological physical therapy on horseback]. Stuttgart: Hippokrates.

Sterba, J. A., Rogers, B. T., France A. P., \& Vokes, D. A. (2002). Horseback riding in children with cerebral palsy: Effect on gross motor function. Developmental Medicine \& Child Neurology, 44:301-308.

Sutherland, D. H., \& Davids, J. R. (1993). Common gait abnormalities of the knee in cerebral palsy. Clinical Orthopaedics and Related Research, 288:139-147.

Sutherland, D. H., Ohlsen, R., Cooper, L., \& Woo, S. L-Y. (1980). The development of mature gait. Journal of Bone \& Joint Surgery, 62-A:336-353.

Taufkirchen, E. (1993). Der gute Sitz auf dem Pferd - Voraussetzung für eine wirksame Hippotherapie [Good sitting on horseback - prerequisite for effective hippotherapy] . Therapeutisches Reiten, 20:9-11.

Verschuren O., Ketelaar M., Takken T., Helders P. J. M., \& Gorter J. W. (2008). Exercise programs for children with cerebral palsy: a systematic review of the literature. American Journal of Physical Medicine and Rehabilitation, 87:404-417.

Wheelwright, E. F., Minns, R.A., Law, H. T., \& Elton, R. A. (1993a). Temporal and spatial parameters of gait in children. I: Normal control data. Developmental Medicine and Child Neurology, 35:102-113. 
Wheelwright, E. F., Minns, R. A., Law, H. T., \& Elton, R. A. (1993b). Temporal and spatial parameters of gait in children. II: Pathological gait. Developmental Medicine and Child Neurology, 35:114-125.

Whittle, M. (1991). Gait Analysis: An Introduction. Oxford: Butterworth, Heineman.

Winchester, P., Kendal, K., Peters, H., Sears, N., \& Winkley, T. (2002). The effects of therapeutic horseback riding on gross motor function and gait speed in children who are developmentally delayed. Physical and Occupational Therapy in Pediatrics, 22:3750.

Wingate, L. (1982). Feasibility of horseback riding as a therapeutic and integrative program for handicapped children. Physical Therapy, 62:184-186.
Winter, D. A. (1990). Biomechanics and Motor Control of Human Movement. New York: John Wiley \& sons.

Zahrádka, L. (1993). Versuche zur Objectivierung von Hippotherpie - Erfolgen bei infantilen Cerebralparetiken [Attempt for objectivity in hippotherapy - success in children with CP]. Therapeutisches Reiten, 20:9-11.

Ölsböck, L. (1992). Wertigkeit der Hippotherapie in der Behandlung cerebralparetischer und mehrfachbehinderter Kinder [The importance of hippotherapy in treatment of children with CP or severe disability]. Therapeutisches Reiten, 19:5-10.

Corresponding author's e-mail address markku.honkavaara@gmail.com

\section{DER EINFLUSS VON KURZZEIT-INTENSIV-HIPPOTHERAPIE AUF DEN GANG VON KINDERN MIT CERBRALPARESE}

(Abstract)

Die Absicht dieser Studie war es, die Auswirkungen einer kurzzeitigen Hippotherapie auf den funktionellen Gang von Kindern mit Cerbralparese (CP) zu untersuchen. Die Teilnehmer/innen waren zwei Jungen (12 und 13 Jahre) mit spastischer Diplegie und ein Mädchen (14 Jahre) mit athetotischer CP. Ein Einzelfall-Design (ABA) wurde verwendet um die quantitativen Veränderungen der Parameter des funktionellen Gangs (Geschwindigkeit, Schrittlänge und -folge) nach den drei Wochen der Hippotherapie zu bestimmen. Die beiden Jungen zeigten Verbesserungen in der Schrittlänge und Ganggeschwindigkeit ohne anhaltender Verbesserung der Schrittfolge. Bei dem Mädchen konnte eine Vergrößerung der Schrittlänge und der -folge festgestellt werden, aber am bemerkenswertesten waren die Verbesserungen in der Geschwindigkeit. Die Ergebnisse deuten somit darauf hin, dass Kurzzeit-Hippotherapie den funktionellen Gang von Kindern mit Cerebralparese verbessern kann.

SCHLÜSSELWÖRTER: Hippotherapie, Cerebralparese, Ganganalyse, Einzelfallstudie

\section{INFLUENCE D'UN PROGRAMME BREF ET INTENSIF D'ÉQUITHÉRAPIE SUR LA MARCHE CHEZ DES ENFANTS INFIRMES MOTEURS CÉRÉBRAUX}

(Résumé)

Le but de cette étude était d'étudier les effets d'un programme court et intense d'équithérapie sur les changements de la marche fonctionnelle chez des enfants infirmes moteurs cérébraux (IMC). Deux garçons âgés de 12 et 13 ans, spastiques diplégiques ainsi qu'une fille, âgée de 14 ans, athétosique ont participé à cette étude. Un protocole expérimental de simple-cas a été 
utilisé afin de déterminer les changements quantitatifs des paramètres de la marche fonctionnelle (vitesse de marche, longueur de pas et cadence) à la suite d'un programme de 3 semaines d'équithérapie. Les 2 garçons ont amélioré leur longueur de pas et leur vitesse de marche seulement. Une augmentation de la longueur de pas ainsi que de la cadence, mais essentiellement de la vitesse de marche, a pu être remarquée pour la fille. Ces résultats indiquent qu'un programme court et intense d'équithérapie contribue à l'amélioration de la marche fonctionnelle chez des enfants atteints d'infirmité cérébrale.

MOTS CLES : Equithérapie, Infirmité Cérébrale, Analyse de la marche, protocole expérimental de simple-cas.

\title{
ВЛИЯНИЕ КРАТКОСРОЧНОЙ И ИНТЕНСИВНОЙ ГИПНОТЕРАПИИ НА ПОХОДКУ ДЕТЕЙ С ЦЕРЕБРАЛЬНЫМ ПАРАЛИЧОМ
}

\author{
(Аннотацця)
}

Целью данного исследования было исследование характера воздействия краткосрочной гипнотерапии на функциональные изменения походки у детей с церебральным параличом (ЦП). Участниками были два мальчика (в возрасте 12 и 13) со спастической дисплегией и девушки (14 лет) с атетоидным ЦП. Для определения количественных изменений функциональных параметров походки (скорость, длина шага и темп) был использован после трех недель гипнотерапии т. н. план исследований на одном объекте (single-subject research designs). Два мальчика продемонстрировали улучшение в длине шага и скорости походки без значительного улучшения в темпе. Существенное увеличение длины шага и темпа у девушки, но наиболее заметные улучшения наблюдались в скорости. Результаты показали, что возможно посредством данной гипнотерапии добиться улучшений функционального состояния походки детей с церебральным параличом.

КЛЮЧЕВЫЕ СЛОВА: гипнотерапия, церебральный паралич, анализ походки, план исследования на одном объекте

\section{LA INFLUENCIA A CORTO PLAZO DE LA HIPOTERAPIA INTENSIVA EN LA MARCHA DE NIÑOS CON PARÁLISIS CEREBRAL}

(Resumen)

El propósito de este estudio fue investigar los efectos de la hipoterapia a corto plazo sobre los cambios funcionales en la marcha de niños con parálisis cerebral. Los participantes fueron dos niños (edades de 12 y 13) con diplejía espástica y una niña (14 años) con parálisis cerebral atetoide. El diseño de un solo sujeto fue utilizado para determinar los cambios cuantitativos en los parámetros funcionales de la marcha (velocidad, longitud de la zancada y cadencia) tras tres semanas de hipoterapia. Los dos niños demostraron una mejoría en la longitud de zancada y velocidad de la marcha, sin una mejora apreciable en la cadencia. En el caso de la niña, hubo un aumento en la longitud de zancada y la cadencia, pero las mejoras más notables fueron en la velocidad. Los resultados indican que es posible que la hipoterapia a corto plazo pueda mejorar la marcha funcional en niños con parálisis cerebral.

PALABRAS CLAVE: Hipoterapia, Parálisis cerebral, Análisis de la marcha, el diseño de un solo sujeto. 


\section{A INFLUÊNCIA DE HIPOTERAPIA INTENSIVA DE CURTA DURAÇÃO NA MARCHA EM CRIANÇAS COM PARALISIA CEREBRAL}

(Resumo)

O objectivo do presente estudo é investigar os efeitos da hipoterapia de curta duração nas modificações funcionais da marcha em crianças com paralisia cerebral (PC). Os participantes foram dois rapazes (idades 12 e 13) com diplegia espástica e uma rapariga (14 anos) com atetose. Foi utilizado um design experimental de estudo de caso (ABA) para determinar as alterações quantitativas nos parâmetros funcionais da marcha (velocidade, tamanho da passada e cadência) após três semanas de hipoterapia. Os dois rapazes demonstraram melhorias no tamanho da passada e na velocidade da marcha sem apresentarem quaisquer melhorias na cadência da marcha. No caso da rapariga verificou-se um aumento do tamanho da passada e da cadência, mas também na velocidade da marcha. Os resultados alcançados indicam que é possível que a hipoterapia de curta duração possa melhorar a marcha funcional em crianças com paralisia cerebral.

PALAVRAS CHAVE: Hipoterapia, paralisia cerebral, análise da marcha, estudo de caso. 